\title{
PROBLEMS OF TL DATING OF THE MESOPLEISTOCENE LOESS DEPOSITS IN THE PODILLYA AND POKUTTYA REGIONS (UKRAINE)
}

\author{
JAROSLAW KUSIAK ${ }^{1}$, MARIA LANCZONT ${ }^{1}$, TERESA MADEYSKA ${ }^{\mathbf{2}}$ and ANDRIJ B. BOGUCKI ${ }^{\mathbf{3}}$ \\ ${ }^{1}$ Department of Physical Geography and Palaeogeography, Maria Curie-Skłodowska University, \\ Al. Kraśnicka 2 cd, 20-718 Lublin, Poland \\ ${ }^{2}$ Institute of Geological Sciences, Polish Academy of Sciences, \\ Twarda 51/55 00-818 Warszawa, Poland \\ ${ }^{3}$ Department of Geomorphology and Palaeogeography, Ivan Franko National University, \\ Doroshenka 41, 79000 Lviv, Ukraine
}

Received 27 May 2010 Accepted 14 November 2012

\begin{abstract}
In many papers different authors was described problem of systematic underestimation of TL ages for sediments older then $100 \mathrm{ka}$. We presented the results which probably are not significantly rejuvenated. This is another example of the TL dates made in Lublin laboratory which are likely in agreement with the stratigraphic interpretation. In 2002 Kusiak et al. published the TL ages ranging from 200 to $800 \mathrm{ka}$ for the Zahvizdja loess profile in Ukraine. These first promising results of TL dating of so old deposits encouraged us to undertake further studies. In next years were discovered other Ukrainian loess profiles with the Middle and Lower Pleistocene deposits, among others in the Skala Podils'ka, Mamalyha and Vendychany sites. The thermoluminescence dating made for these profiles in the Lublin laboratory gave the next, after Zahvizdja, series of 15 TL ages ranging from 200 to 700 ka. This way we confirmed the possibility of TL dating of the deposits older than $400 \mathrm{ka} \mathrm{BP}$.
\end{abstract}

Keywords: TL dating, loess-soil sequence, Mesopleistocene, Podillya and Pokuttya regions.

\section{INTRODUCTION}

The methods of absolute dating give a timeframe for the description of climate changes in the Quaternary. There are several such methods. The most important geochronological methods are based on the following physical phenomena: radiocarbon method $\left({ }^{14} \mathrm{C}\right)$ on radioactive decay, uranium-thorium $(\mathrm{U} / \mathrm{Th})$ and potassiumargon $(\mathrm{K} / \mathrm{Ar})$ on accumulation of radiogenic nuclides, thermoluminescence (TL), optically stimulated luminescence (OSL) and electron paramagnetic resonance (EPR) on the record of radiation effect on minerals. The palae- omagnetic dating method also should be mentioned.

In order to arrange chronologically the sedimentation stages of Neopleistocene and Mesopleistocene loesses the thermoluminescence and palaeomagnetic methods can be widely used. In case of the Upper Pleistocene deposits it is also possible to use the OSL and ${ }^{14} \mathrm{C}$ methods; the latter only when an admixture of organic material (plant remains, humus of paleosols and the like) occurs in loess deposits.

Special importance of the thermoluminescence method for dating of loess deposits results from its specificity. It enables us to date the time of material deposition, i.e. the time of deposit layer formation. It can be widely used due to availability of mineral material. 
However, the age extent of the TL method applicability is differently determined by different authors. In the opinion of Fedorowicz (2006), the reliable dating results can be obtained for the deposits to 250-300 ka old. Bluszcz (2000) and Frechen et al. $(1997,1999)$ think that the deposits older than 300-400 ka BP cannot be correctly dated. The extreme position is represented by Berger et al. (1992) and Kusiak et al. (2002). They think that reliable results of thermoluminescence dating can be obtained for loess deposits to about $800 \mathrm{ka} \mathrm{BP}$ old but with the reservation that dating could be difficult if the equivalent dose considerably exceeds 2000 Gy and the TL signal is almost saturated. This is the cause of rather big errors in the determination of equivalent dose and thus the TL age (Kusiak, 2002; Kusiak et al., 2002).

The results of thermoluminescence dating of the Zahvizdja loess-soil sequence in Ukraine were published by Kusiak (2002) and Kusiak et al. (2002). In this profile the Matuyama-Brunhes boundary (further: MBB - $788 \mathrm{ka}$ ) was found as a result of palaeomagnetic investigations (Nawrocki et al., 2002). These promising TL dating results, the first ones obtained for the western Ukraine that range from 200 to $800 \mathrm{ka} \mathrm{BP}$, encouraged the research team under the management of M. Łanczont and A. Bogucki to undertake further studies on the TL dating of Mesopleistocene loess deposits in the Skala Podils'ka, Mamalyha and Vendychany profiles (Fig. 1). In this paper we report the TL dating results from these sites together with those obtained earlier for the Zahvizdja profile.

All mentioned profiles are situated in the zone of suband meta-Carpathian loess uplands. The most distant sites are situated at about $160 \mathrm{~km}$ apart along the parallel and about $80 \mathrm{~km}$ along the meridian. These different locations result in distinct regional differences of litho- and pedological features but the obtained TL dating results are comparable and give us the excellent opportunity to correlate the examined profiles in respect of their chronostratigraphy.

\section{GEOGRAPHICAL SETTINGS OF THE STUDY SITES}

The investigated sites occur in the southern part of the Podillya Upland, in the following units of lower rank: Western Podillya (Skala Podil'ska site) and Eastern Podillya (Vendychany site), which are together called the Podillya lying beyond the Dniester (Czyżewski, 1931), and which are separated by the Dniester River valley from the Pokuttya region (Mamalyha site) stretching to the Prut River valley (Rehman, 1893). The earlier investigated Zahvizdja profile occurs in the East Carpathian Foreland (Fig. 1).

In geological structure of the Podillya Upland we distinguish the East-European crystalline shield covered by Palaeozoic, Cretaceous and Neogene complex of clastic and carbonate rocks. These are different limestones (Skala Podil'ska site), sandstones (Vendychany site), and gypsum rocks (Mamalyha site). In respect of geomorphology the upland is slightly inclined plateau. Parallel, sub-meridional narrow valleys of canyon type, with great inclination and steep sides, divide this plateau into rather wide, flat ridges, which are cut from the south by the steep wall of the Dniester River canyon-type valley (D’Abancourt, 1927; Bogucki et al., 2009; Cys', 1962; Czyżewski, 1928). Trough-like, shallow, dry, small valleys (so-called balka) forming branched systems are one the main elements diversifying the upland plateau relief

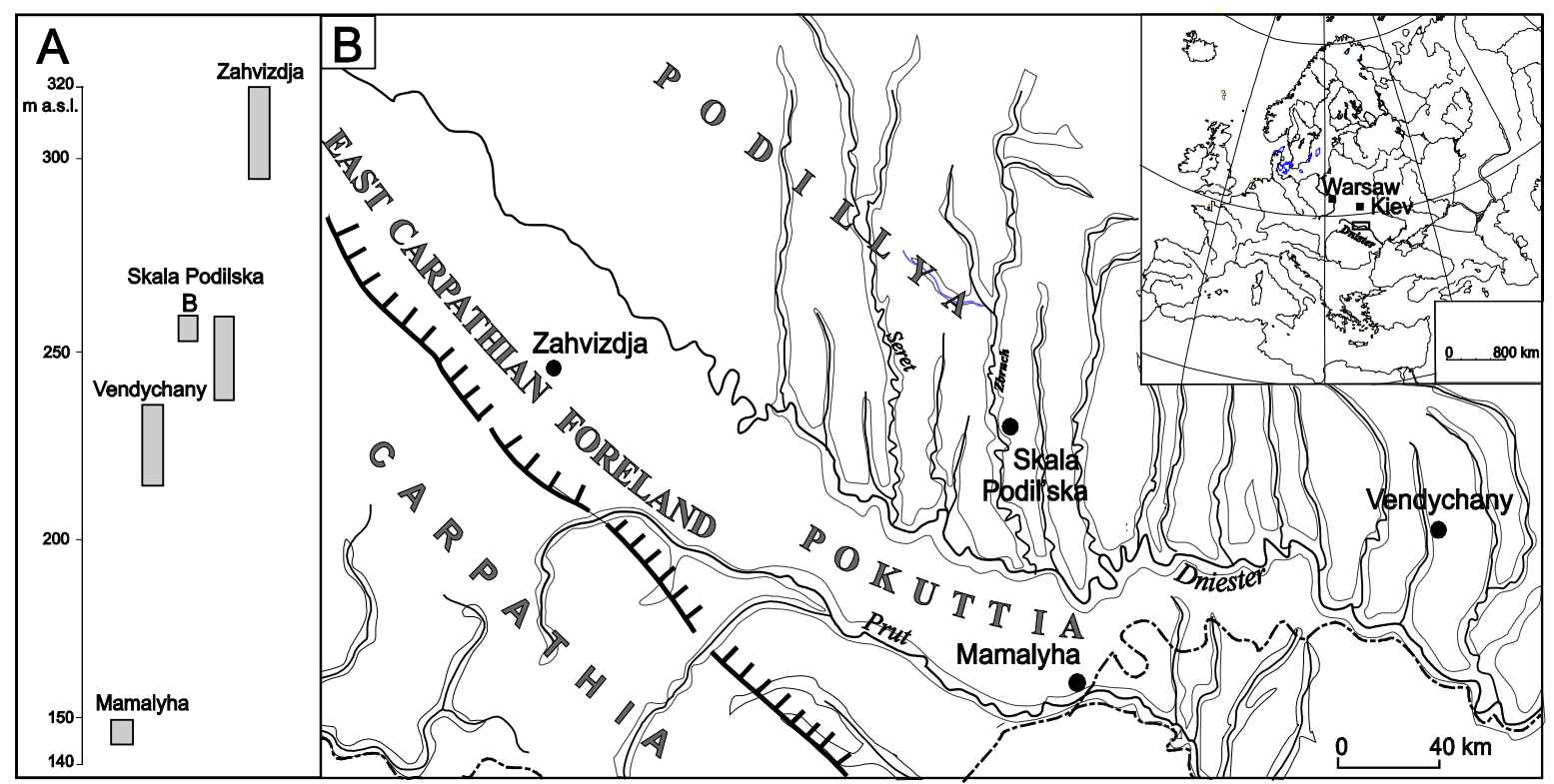

Fig. 1. Location (B) and hypsometric position (A) of study sites. 
(Rehman, 1893). The Dniester and Prut interfluve (Pokuttya region) is characterized by the occurrence of landscape units forming belts of parallel arrangement. In the north it is a high ridge of watershed adjoining the Dniester River valley, which is strongly asymmetric in this part. Slightly undulated plateau occurring in the south is inclined towards the Prut River valley and dissected by its tributary valleys but to a much lesser degree than the Podillya Upland (Cys', 1962; Czyżewski, 1931; Rehman, 1893; Zglinnica, 1931). Small karst lakes and karst dolines developed in gypsum and reproduced in loess are typical element of the landscape (Zglinnica, 1931).

The East Carpathian Foreland region is a part of the zone of the Alpine tectonic depressions of the Carpathian Foredeep. The Zahvizdja site is situated in the foredeep outer zone, which adjoins the Podillya Upland platform. The Krakowiec clays from the younger Neogene underlie the Quaternary deposits. The relief of this region is characterized by two main elements: large valleys of rivers flowing from the Carpathians, and vast, almost flat watershed areas covered by the alluvia of pre-Dniester River (Teisseyre, 1933; Lanczont et al., 2003).

A common feature of this part of Ukraine is the occurrence of loess. Thick loess deposits, mostly older units, are widespread on high river terraces and on interfluves' areas. These loess sequences are characterized by the occurrence of alternating loess and paleosols which reflect climatic oscillations/variability as well as sediment supply in the region during Mesopleistocene. Younger loesses occur only on the terraces developed on the sides of river deep valleys. They also fill erosion-denudation small valleys so some of them are buried.

\section{DESCRIPTION OF SITES}

The Podillya loess sequence represents a unique environment of sedimentation, characterized by relatively weak intensity of loess deposition processes, and relatively strong intensity of pedogenesis (well-developed interglacial palaeosols) and post-deposition processes, which have often truncated soils to a different degree. The sections transformed by pedogenesis predominate in the examined profiles. However, striking features of most paleosols in the Podillya loesses are considerable destruction of their profiles, secondary transformation of morphological horizons, bioturbations and big discontinuous deformations, e.g. deep, probably desiccation fissures dividing the paleosols into separate blocks (Lanczont and Madeyska, 2009). These deep fissures are filled with soil material or loess. Paleosols are directly superimposed (e.g. in the Vendychany profile) or separated by usually thin loess units (e.g. in the Skala Podils'ka profile).

The stratigraphy of the examined profiles was presented basing on combined geologic, palaeopedologic, and partially palaeobiologic (Skala Podil'ska) criteria with reference to the results of palaeomagnetic and ther- moluminescence analyses. Combined letter-number symbols were used to denote stratigraphic loess $\mathbf{L}$ and soil $\mathbf{S}$ units (Bogucki and Łanczont, 2002). Moreover, the profiles were correlated with the Quaternary stratigraphic schemes of Ukraine and Poland (Ber, 2005; Lindner et al., 2006). Regional names from the western Ukraine (Bogucki and Lanczont, 2002) and according to the Ukrainian Geological Survey (Gozhik et al., 1995; Veklich, 1982) were used for soil and loess units.

\section{Zahvizdja site}

The profile at Zahvizdja (Fig. 2), described by Łanczont and Bogucki (2002), represents deposit cover on the high terrace in the Bystrycja River valley, a tributary of the Dniester River. The Quaternary deposits in this profile are about $22 \mathrm{~m}$ thick. Three main lithologic units can be distinguished in them. The $15 \mathrm{~m}$ thick upper unit is loess-soil series, the middle unit (about $4 \mathrm{~m}$ ) contains the pedocomplex of four paleosols, and the lower unit (about $2 \mathrm{~m}$ ) is composed of fluvial deposits (silts, sands and gravels). All paleosols are forest soils of different degree of pedogenesis development.

In comparison with the Podillyan loesses, in the Zahvizdja profile the loess-soil sequence in the upper part of the cover is more complex (Lanczont et al., 2003). Besides the near-surface soil, which resembles the soil $\mathrm{S} 2=$ Korshiv/Kaydaki unit (corresponding to the Lublinian Interglacial), two fossil pedocomplexes are found. The middle one, $\mathrm{S} 3+\mathrm{S} 4$, is correlated with the Luck+Sokal units (=Zavadivka unit) from the Great Interglacial s.l., and it has not a counterpart in the examined Podillyan profiles. The lower one corresponds stratigraphically but not typologically to the S5-I and S5-II pedocomplex $=$ Solotvyn/Lubny unit (from the Ferdynandovian Interglacial). The particular soils and pedocomplexes are separated by the loess L3=Dnieper unit (from the Odranian Glacial) and loess L5=Tiligul unit (Sanian 2 Glacial). Loess and other deposits evidencing cold climate were also found between the Solotvyn soils (Lanczont et al., 2003). They are underlain by the loess L6=Sula unit (from Sanian 1 Glacial). The underlying soils of the middle unit are very different from the Podillyan soils occurring in similar stratigraphic position. These are four well-developed forest soils, directly superimposed on each other, and the lowest is developed on alluvia. Each has the full profile with three horizons. All have traces of very intense postgenetic plastic deformations in the form of convolutions (involution-injection structures) of the horizons A and E. The Zahvizdja regional pedocomplex is named after these soils. The MBB is found in the soil third from top. According to the regional stratigraphic scheme these are the soils S6-I, S6-II, S7, S8, and they correspond to the Martonosha and Shyrokhyno (younger part) units (Bogucki and Łanczont, 2002). They can be correlated with the Małopolanian and Augustovian Interglacials. 


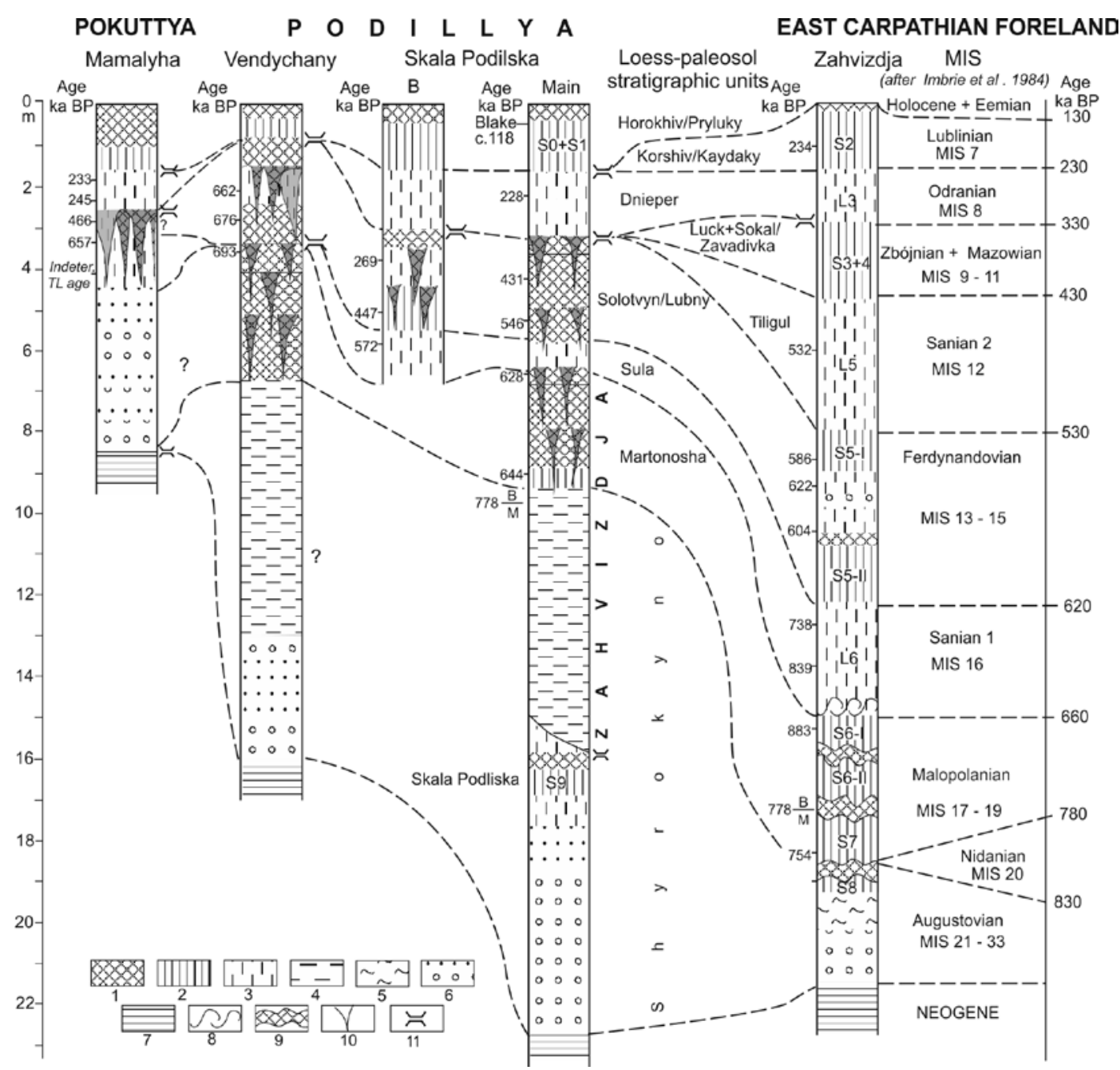

Fig. 2. Stratigraphic setting in relation to the Quaternary stratigraphic schemes in Ukraine and Poland (according to Bogucki and Łanczont (2002), Gozhik et al. (1995), Lindner et al. (2006), Veklich (1982)) and thermoluminescence age of Pleistocene deposits in study sites. 1 - A horizon of modern and fossil soils; 2 - B horizon of modern and fossil soils; 3 - loess; 4 - clayey silts; 5 - silt; 6 - sand and gravel; 7 - Neogene deposits; 8 - solifluction tongues; 9 - involution disturbances; 10 - cryogenic wedges; 11 - hiatus.

\section{Skala Podil'ska}

The Skala Podils'ka profile is a unique record of the Quaternary palaeoenvironmental changes in the Podillya Upland region (Bogucki et al., 2009; Lanczont and Madeyska, 2009). The Matuyama-Brunhes boundary (MBB) was found in this profile, and the Blake episode was identified in the near-surface soil. These two data allow us to define the formation time of a considerable part of the Pleistocene deposits in the site. The deposits were examined in several places of the site but thermoluminescence dating was carried out only in the main profile and the profile $\mathrm{B}$.

The profile contains altogether seven superimposed paleosols, which form four pedocomplexes separated by loess layers of different thickness and a series of paludal deposits (Fig. 2). Almost all these soils are strongly af- fected by surface erosion and (except for the oldest one) dissected by fissure systems (Bogucki et al., 2009).

The upper part of profile consists of loess-soil sequence about $10 \mathrm{~m}$ thick, which contains three pedocomplexes separated by two loess layers. The near-surface chernozem superimposed on forest soil has relict features. Palaeomagnetic investigations indicate that it is the Holocene-Eemian pedocomplex $(\mathrm{S} 0+\mathrm{S} 1)$. It is separated by the loess L3 from the middle pedocomplex of two chernozem-type soils (S5-I and S5-II). Thin layer of loess L6 separates these soils from the pedocomplex of three forest soils with distinctive red-brown colours and calcareous clayey silts up to $5 \mathrm{~m}$ thick, with the layers of large calcareous concretions. The MBB is found in the top part of the silts. We think that these three soils (i.e. S6-I, S6-II and S7) and silt deposit correspond to the Zahvizdja unit. The underlying pedocomplex is up to $4 \mathrm{~m}$ thick and com- 
posed of meadow soil superimposed on forest soil, which developed on loess or loess-like deposit. This soil was given the regional name "Skala Podils'ka" and symbol S9. The lower part of the Skala Podils'ka profile consists of fluvial deposits of the high terrace of the Zbruch River. Sands and gravels composed of the Carpathian and local material form about $5 \mathrm{~m}$ thick bed. Based on paleontological and palinological data, this bed can be correlated with the Late Eopleistocene (Krochmal et al., 2009), i.e. to the Shyrokyno 3 (personal communication M. Komar and A. Krochmal).

\section{Vendychany site}

The Vendychany profile is situated in the southern slope of the Podillyan plateau, about $25 \mathrm{~km}$ from the Dniester River valley. It represents the cover deposit series of the high terrace of the Dniester River. The examined deposits are exposed in the head wall of the landslide destroying the edges of the large excavation where the Neogene marine clays are exploited. There are some analogies between the profiles in Vendychany and Skala Podils'ka. The Vendychany profile contains altogether six paleosols, which form three pedocomplexes. The near-surface, $0.8 \mathrm{~m}$ thick soil $\mathrm{S} 0+\mathrm{S} 1$ (?) is composed of chernozem superimposed on forest soil. Sharp linear boundary separates this soil from the S5-I and S5-II pedocomplex of chernozem-type soils, with the A- $\mathrm{B}_{\mathrm{Ca}}$ profile, $2.5 \mathrm{~m}$ thick. The structures of wedge-like fissures dissecting these soils are filled with pale loess, which is preserved outside them only as small fragments. The next pedocomplex of three soils with intense brown-rust colour are correlated with the part of the Zahvizdja unit (S6I, S6-II, S7). These are illuvial horizons of forest soils with total thickness of almost $3.5 \mathrm{~m}$. Fissures occurring in these soils are filled with gley material. They dissect the whole thickness of particular horizons and even reach deeper. The lower part of the profile consists of 4-6 m thick, carbonate-free, spotty, rust-coloured and bluishgrey loams and about $3 \mathrm{~m}$ thick sandy-gravelly fluvial series. These gravels are composed only of the very resistant Carpathian material. Stratigraphic correlation of these two units is difficult.

\section{Mamalyha site}

The profile of Quaternary deposits overlying Badenian gypsum is exposed in a quarry (Bogucki and Łanczont, 2009). It contains two deposit series of the Prut River high terrace: loess-soil $(4.5 \mathrm{~m})$ and fluvial sandygravelly $(4.5 \mathrm{~m})$. The investigations were carried out in two exposures: Mamalyha 1 and Mamalyha 2. Besides the near-surface soil (similar to the complex found in Vendychany and Skala Podils'ka profiles), only the Solotvyn unit (S5-I and S5-II) occurs in the Mamalyha site. It is covered by the loess L3 and underlain by bipartite bed of strongly gleyed loess-like deposits L6. Fossil pedocomplex can be examined in the eastern part of the quarry (Mamalyha 2). In the southern part (Mamalyha 1) the soils were destroyed by denudation which left only the fragments of wedge structures filled with soil material from the horizon B. These structures, about $1 \mathrm{~m}$ deep and rather narrow, occur at 1-metre intervals. It is clear that they are lower part of wedges. The upper parts were destroyed together with the genetic horizons of soils dissected by them. These wedge structures overlap and cross each other, and are additionally cut by a system of wedge-like fissures of third generation. The latter ones start from the overlying loess and are filled with it. Some features of the third generation fissures indicate that they are probably cryogenic structures.

\section{DATING METHOD}

In the Lublin laboratory the TL age is determined as a quotient of equivalent dose $\left(D_{e}\right)$ and dose rate $\left(D_{r}\right)$ according to standard method. The dose rate is measured by gamma spectrometry method. Corrections for deposit moisture and cosmic radiation are calculated. The equivalent dose is determined by the total-bleach method described by Singhvi et al. (1982). The dating method was described in detail by J. Kusiak in Lanczont et al. (2011). In this study was used the BG-28 optical filter during thermoluminescence measurements. Before the TL measurements the subsamples of mineral material were preheated at $160^{\circ} \mathrm{C}$ for 3 hours. Thermoluminescence light sum was read as the surface area under the $270-280^{\circ} \mathrm{C}$ region of the TL glow curve, which included its maximum.

\section{RESULTS}

The complete TL dating results are presented in Table 1. In Fig. 2 they are listed in a simplified form, without the uncertainty limits. Fig. 2 contains also the duration of oxygen-isotope stages corresponding to the particular glacial and interglacial stratigraphic units after Imbrie et al. (1984).

In the Skala Podils'ka site, the following five samples were taken from the main profile, from top to bottom: sample from the L3 loess, was TL dated at $228 \pm 42 \mathrm{ka}$ (Lub-4201), two samples from the deposits, which are correlated with the Solotvyn/Lubny unit, were dated at $431 \pm 94 \mathrm{ka}$ (Lub-4202) and 546 $\pm 114 \mathrm{ka}$ (Lub-4203). Three samples were taken from the Zahvizdja pedocomplex but the TL signal of the middle one (Lub-4205) was saturated and its TL age was not determined. The upper soil was TL dated at $628 \pm 202 \mathrm{ka}$ (Lub-4204), and the lower soil (horizon $\mathrm{B}_{\mathrm{Ca}}$ ) - at 644 $\pm 219 \mathrm{ka}$ (Lub-4206).

The supplementary profile in the Skala Podils'ka site was denoted with letter B. It was selected for detailed investigations because of the Solotvyn pedocomplex peculiarities. These soils are separated and underlain by carbonate loess. The upper soil has complete profile $\left(\mathrm{A}-\mathrm{B}_{\mathrm{C}}\right)$, and contains pockets of loess material incorporated 
Table 1. Results of TL dating.

\begin{tabular}{|c|c|c|c|c|}
\hline Depth (m) & Lab. No & $\begin{array}{l}\text { Dose rate } \\
\text { Dr (Gy/ka) }\end{array}$ & $\begin{array}{c}\text { Equivalent dose } \\
D_{e}(G y)\end{array}$ & $\begin{array}{c}\text { TL age } \\
\text { (ka) }\end{array}$ \\
\hline \multicolumn{5}{|c|}{ Skała Podolska profile } \\
\hline 2.20 & Lub-4201 & $2.96 \pm 0.21$ & $674 \pm 116$ & $228 \pm 42$ \\
\hline 4.20 & Lub-4202 & $3.04 \pm 0.24$ & $1311 \pm 267$ & $431 \pm 94$ \\
\hline 5.20 & Lub-4203 & $2.78 \pm 0.25$ & $1520 \pm 286$ & $546 \pm 114$ \\
\hline 6.55 & Lub-4204 & $3.28 \pm 0.26$ & $2057 \pm 640$ & $628 \pm 202$ \\
\hline 7.50 & Lub-4205 & $3.17 \pm 0.22$ & Saturation TL & Indeterminable TL age \\
\hline 9.00 & Lub-4206 & $3.23 \pm 0.26$ & $2083 \pm 689$ & $644 \pm 219$ \\
\hline \multicolumn{5}{|c|}{ Skała Podolska B profile } \\
\hline 0.70 & Lub-4283 & $2.48 \pm 0.22$ & $667 \pm 116$ & $269 \pm 52$ \\
\hline 2.00 & Lub-4284 & $3.19 \pm 0.27$ & $1427 \pm 245$ & $447 \pm 85$ \\
\hline 2.80 & Lub-4285 & $3.34 \pm 0.27$ & $1911 \pm 420$ & $572 \pm 132$ \\
\hline \multicolumn{5}{|c|}{ Vendyczany profile } \\
\hline 2.10 & Lub-4286 & $2.87 \pm 0.26$ & $1782 \pm 339$ & $622 \pm 131$ \\
\hline 2.80 & Lub-4287 & $2.95 \pm 0.27$ & $1994 \pm 459$ & $676 \pm 169$ \\
\hline 3.60 & Lub-4288 & $3.00 \pm 0.28$ & $2077 \pm 519$ & $693 \pm 187$ \\
\hline \multicolumn{5}{|c|}{ Mamałyga profile } \\
\hline 1.80 & Lub-4289 & $2.99 \pm 0.28$ & $696 \pm 123$ & $233 \pm 47$ \\
\hline 2.30 & Lub-4290 & $2.70 \pm 0.25$ & $662 \pm 128$ & $245 \pm 51$ \\
\hline 3.00 & Lub-4291 & $3.18 \pm 0.26$ & $1484 \pm 286$ & $466 \pm 98$ \\
\hline 3.35 & Lub-4292 & $2.73 \pm 0.25$ & $1795 \pm 377$ & $657 \pm 151$ \\
\hline 4.10 & Lub-4293 & $1.74 \pm 0.19$ & Saturation TL & Indeterminable TL age \\
\hline \multicolumn{5}{|c|}{ Zahvizdja profile } \\
\hline 1.00 & Lub-3680 & $3.66 \pm 0.40$ & $856 \pm 144$ & $234 \pm 47$ \\
\hline 6.00 & Lub-3681 & $3.45 \pm 0.26$ & $1831 \pm 327$ & $532 \pm 101$ \\
\hline 8.70 & Lub-3682 & $2.55 \pm 0.23$ & $1497 \pm 269$ & $586 \pm 117$ \\
\hline 9.30 & Lub-3683 & $3.17 \pm 0.41$ & $1969 \pm 479$ & $622 \pm 174$ \\
\hline 10.50 & Lub-3684 & $2.92 \pm 0.36$ & $1762 \pm 460$ & $604 \pm 174$ \\
\hline 12.70 & Lub-3675 & $3.36 \pm 0.30$ & $2478 \pm 669$ & $738 \pm 207$ \\
\hline 13.70 & Lub-3676 & $3.38 \pm 0.24$ & $2833 \pm 896$ & $839 \pm 277$ \\
\hline 15.30 & Lub-3677 & $2.92 \pm 0.35$ & $2577 \pm 1126$ & $883 \pm 398$ \\
\hline 18.30 & Lub-3678 & $3.17 \pm 0.38$ & $2386 \pm 916$ & $754 \pm 301$ \\
\hline 19.50 & Lub-3679 & $3.22 \pm 0.35$ & Saturation TL & Indeterminable TL age \\
\hline
\end{tabular}

through fissures or zoogenic tunnels. The horizon $\mathrm{B}_{\mathrm{Ca}}$ of the soil S5-I was dated at $269 \pm 52 \mathrm{ka}$ (Lub-4283) but this TL age better corresponds to the overlying loess L3. This was probably caused by the admixture of younger loess material. The lower soil S5-II is strongly destroyed. The material of horizon $\mathrm{A}$ is preserved only in fissures. The horizon $\mathrm{B}_{\mathrm{Ca}}$ was TL dated at $447 \pm 85 \mathrm{ka}$ (Lub-4284). The loess L 6 was dated at $572 \pm 31 \mathrm{ka}$ (Lub-4285). Therefore, in general the TL dating results of the Skala Podils'ka profile well correspond to the expected age and stratigraphic interpretation based on wide criteria.

In the Vendychany profile only three samples were dated by TL. Two of them taken from the deposits correlated with the Solotvyn/Lubny pedocomplex. The horizon $\mathrm{B}_{\mathrm{Ca}}$ of the soil S5-I was dated at $622 \pm 131 \mathrm{ka}$ (Lub-4286) and the humus horizon of the soil S5-II - at $676 \pm 169 \mathrm{ka}$ (Lub-4287). These results are slightly overestimated in comparison with the duration of the MIS13-15. They probably reflect the age of parent material on which the soils developed. This is an important question, which demands detailed analysis of the pedogenesis conditions in the context of the possibility of syngenetic supply of fresh mineral material. The TL age of the third sample (Lub-4288) from the youngest soil (probably S6-I) of the Zahvizdja pedocomplex is $693 \pm 187 \mathrm{ka}$, and it well corresponds to the stratigraphic interpretation of the profile and to the MIS 17-19.

In the Mamalyha 1 profile only loess layers were dated by TL. Two samples taken from the loess correlated with L3 were dated at $233 \pm 47$ ka (Lub-4289) and $245 \pm 51 \mathrm{ka}$ (Lub-4290), and the results well correspond to this stratigraphic interpretation (MIS 8). One sample (Lub-4291) was experimentally taken from homogeneous material filling the wedge-like structure. This structure is assumed to be of the post-Solotvyn age and cryogenic origin, and the filling material - contemporary loess. The obtained TL age $(466 \pm 98 \mathrm{ka})$ indicates that it can be loess L5. Two next samples were taken from the bipartite layer of loess-like deposit underlying the above-described remains of the loess S5. The higher lying sample (Lub4292) was dated at $657 \pm 151 \mathrm{ka}$, and can be correlated with the loess L6. These four results generally well correspond to the stratigraphic interpretation of the profile. 
TL age was not determined only for the sample Lub-4293 because the TL signal was saturated.

The presented results of TL dating from the Podillya region are comparable with those obtained for the Zahvizdja profile. Five TL dates, ranging from $234 \pm 47$ to $622 \pm 174 \mathrm{ka}$, were obtained for a part of this profile from the Korshiv/Kaydaki unit to the Solotvyn/Lubny unit. These results correspond well to the stratigraphic interpretation of the profile. However, the TL ages of two next samples taken from the loess L6 are overestimated ( $738 \pm 207$ and $839 \pm 277 \mathrm{ka}$ ). This fact can be evidence for the change of loess depositional conditions. We can assume that while fresh dust was accumulated in younger loess layers, the older layers were formed as a result of short episodes of deflation of older covers. This is also probably the reason that the TL age of the soil S6-I, the youngest one in the Zahvizdja pedocomplex, is considerably overestimated $(883 \pm 398 \mathrm{ka})$. On the other hand, we obtained an interesting result for the soil third from top, i.e. in which the MBB was found. Its TL age $(744 \pm 301$ $\mathrm{ka}$ ) is only slightly different, taking into account the error margin, from the boundary of palaeomagnetic epochs determined at $788 \mathrm{ka} \mathrm{BP}$. From among four soils this one is the best preserved, most completely developed and thickest.

\section{FINAL REMARKS}

The attempts at dating of the Mesopleistocene deposits in Ukraine made in the last years were successful. The research work carried out in the Skala Podils'ka, Mamalyha and Vendychany sites gave the series of TL dating results for 200-700 ka old loess deposits. This way we confirmed the possibility of obtaining the thermoluminescence dating results exceeding $400 \mathrm{ka}$.

An important problem to be clarified is why different authors give different age extents of the TL method applicability. This fact results from the differences between analytical techniques. The above-mentioned TL dating results obtained for the Zahvizdja profile can be a contribution to explanation of this issue. Kusiak (2002) and Kusiak et al. (2002) published the results obtained using several modifications of the thermoluminescence method. The values of equivalent dose obtained by regeneration method were considerably lower than those obtained for the same samples by total-bleach method. J. Kusiak could not obtain the equivalent dose values exceeding $1000 \mathrm{~Gy}$ (i.e. the TL ages over 300-370 ka) by regeneration method. It is consistent with the opinions about the upper limit of the TL method applicability published by other authors. The total-bleach method has not such limitation. The ED values obtained for the Zahvizdja profile increase with depth to about $2500 \mathrm{~Gy}$, i.e. to the TL age about $800 \mathrm{ka}$. The use of total-bleach method enables us to obtain the equivalent dose values reaching 2000 Gy (i.e. the TL age to $700 \mathrm{ka}$ ) for the deposit samples taken from the Skala Podils'ka, Vendychany and Mamalyha. Besides the problems resulting from measurement techniques, the differences between dating results can be also explained by the influence of deposition and redeposition conditions as well as post-depositional deformations. The occurrence of discontinuous deformations, especially of deep fissures, created favourable conditions for younger material to get inside older layers. If lithologic differences are big, we can avoid a mistake by very careful selection of samples. If lithologic differences are small, e.g. as a result of repeated pedogenesis, it is very difficult. Such repeated soil processes are undoubtedly recorded in the Skala Podils'ka and Vendychany profiles. In many loess profiles we find hiatuses caused not only by breaks in deposition but also by the development of denudation processes. Partial denudation of deposits, exposition of older ones and then their rapid or massive redeposition can result in not complete zeroing of thermoluminescence clock. Such a situation could have occurred at Zahvizdja. Bioturbations, which are also common in loess profiles, can result in local mixing of material of different ages. If lithologic diversity is small, their occurrence can be also very difficult to find, and they can result in overestimation or underestimation of the obtained TL ages. Traces of pedofauna activity are common in the Podillya loesses.

Moreover, we should always take into account the measurement uncertainty, which can by high, and probabilistic interpretation of the obtained dating results, as in case of radiocarbon analyses (Walanus and Goslar, 2009).

\section{ACKNOWLEDGEMENTS}

This work has been done as part of the project 3 P04D 03425 financed by the Polish State Committee for Scientific Research. We would like to express our gratitude to Mgr. Ewa Sadowska for the graphic preparation of the figures and to Dr. Maria Wilgat who prepared the English version of this paper.

\section{REFERENCES}

Ber A, 2005. Polish Pleistocene stratigraphy - A review of interglacial stratotypes. Netherlands Journal of Geosciences. Geologie en Mijnbouw 84(2): 61-76.

Berger GW, Pillans BJ and Palmer AS, 1992. Dating loess up to $800 \mathrm{ka}$ by thermoluminescence. Geology 20(5): 403-406, DOI 10.1130/0091-7613(1992)020<0403:DLUTKB>2.3.CO;2.

Bluszcz A, 2000. Datowanie luminescencyjne osadów czwartorzędowych - teoria, ograniczenia, problemy interpretacyjne. Zeszyty Naukowe Politechniki Ślaskiej, seria Mat. Fiz., Z. 86, Geochronometria, 17: 104pp (in Polish).

Bogucki (Boguckyj) AB and Łanczont M, 2002. Stratygrafia lessów Naddniestrza Halickiego (Loess stratigraphy in the Halyč Prydnistrov'ja region). In: Madeyska T, ed, Lessy i paleolit Naddniestrza halickiego (Ukraina) (Loess and Palaeolithic of the Dniester River Basin, Halyč region (Ukraine)). Studia Geologica Polonica 119: 315-327 (in Polish).

Bogucki (Boguckij) A and Łanczont M, 2009. Rozriz plejstocenowich widkładiw Mamałyga na Pokutti (The profile of Pleistocene deposits in the Mamalyha site in the Pokuttya region). In: Bogucki A ed, Najdawnyszi lesi Podilija o Pokutjtja, problemy genezy, 
stratygrafii, paleogeografii (The oldest loesses of the Podillya and Pokuttya regions: problems of origin, stratigraphy and palaeogeography). Wyd. Centr. LUN im. I. Franko, Lviv: 147-193 (in Ukrainian).

Bogucki (Boguckij) AB, Łanczont M, Łącka B, Madeyska $\mathrm{T}$ and Nawrocki J, 2009. Quaternary sediment sequence at Skala Podil'ska, Dniester River basin (Ukraine): Preliminary results of multi-proxy analyses. Quaternary International 198(1-2): 173194, DOI 10.1016/j.quaint.2008.05.010.

Cys' PM, 1962. Geomorfologia URSR (Geomorphology URSR). Wydawnictwo Lvivskoho Uniwersytetu: 221 pp (in Ukrainian).

Czyżewski J, 1928. Z historji doliny Dniestru (From the history of the Dniestr River valley). Prace Geograficzne Wydawane przez prof. E. Romera 10: 33-65 (in Polish).

Czyżewski J, 1931. Z fizjografji Pokucia (Physiography of the Pokuttya). Prace Geograficzne Wydawane przez prof. E. Romera 12: 533 (in Polish).

D’Abancourt A, 1927. Klasyfikacja i rozwój dolin podolskich (Classification and the development of the Podolian valleys). Prace Geograficzne Wydawane przez prof. E. Romera 9: 1-26 (in Polish).

Fedorowicz S, 2006. Metodyczne aspekty luminescencyjnego oznaczania wieku osadów neoplejstoceńskich Europy Środkowej (Methodological aspects of luminescencje dating of Central Europe's Neopleistocene deposits). Wydawnictwo Uniwersytetu Gdańskiego: $156 \mathrm{pp}$ (in Polish).

Frechen M, Horváth E and Gábris G, 1997. Geochronology of Middle and Upper Pleiscene loess sections in Hungary. Quaternary Research 48(3): 291-312, DOI 10.1006/qres.1997.1929.

Frechen M, Zander A, Cilek V and Ložek V, 1999. Loess chronology of the Last Interglacial /Glacial cycle in Bohemia and Moravia, Czech Republic. Quaternary Science Reviews 18(13): 1467-1493, DOI 10.1016/S0277-3791(98)00087-0.

Gozhik P, Shelkoplyas V and Khristophorova T, 1995. Development stages of loessial and glacial formations in Ukraine. Stratigraphy of Loesses in Ukraine. Annales UMCS, sec. B, 50, 65-74. Lublin.

Imbrie J, Hays J, Martinson D, McIntyre A, Mix AC, Morley JJ, Pisias NG, Prell WL and Shackleton NJ, 1984. The orbital theory of Pleistocene climate: Support from a revised chronology of the marine delta ${ }^{18} \mathrm{O}$ record. In: Berger AL, Imbrie J, Hays J, Kukla G and Saltzman B eds, Milankovitch and Climate, Part 1, Reidel, Dordrecht: 265-351.

Krohmal A, Komar M and Prylypko S, 2009. Rezultaty paleontologičeskoj ekspertyzy alluvialnyh otloženij eoplejstocenovoj terrasy $\mathrm{r}$. Zbruč w rajonie Skala Podilskaja (Ternopilskaja oblast) (Results of palaeontological analysis of alluvial deposits of the Eopleistocene terrace of the Zbruch River in the Skala Podil'ska area (Ternopil district)). In: Bogucki A ed, Najdawnyszi lesi Podilija o Pokutitja, problemy genezy, stratygrafii, paleogeografii (The oldest loesses of the Podillya and Pokuttya regions: problems of origin, stratigraphy and palaeogeography). Wyd. Centr. LUN im. I. Franko, Lviv: 166-168 (in Ukrainian).

Kusiak J, 2002. Problem wyboru procedury pomiarowej w analizie termoluminescencyjnej na przykładzie datowania profilu Zahvizdja (Selection of measurement method in the TL analysis on the basis of dating of the Zahvizdja profile). In: Madeyska T, ed, Lessy $i$ paleolit Naddniestrza halickiego (Ukraina) (Loess and Palaeolithic of the Dniester River Basin, Halyč region (Ukraine)), Studia Geologica Polonica 119: 193-197 (in Polish).

Kusiak J, Łanczont M, Bogucki (Boguckyj) A and Wojtanowicz J, 2002. Divergence in the TL dating resulting from different methods of equivalent dose determination. Geochronometria 21: 27-32.

Lindner L, Bogucki A, Gozhik P, Marks L, Łanczont M and Wojtanowicz J, 2006. Correlation of Pleistocene deposits in the area between the Baltic and Black Sea, Central Europe. Geological Quarterly 50 (1): 195-210.

Łanczont M and Bogucki (Boguckyj) A, 2002. Badane profile lessowe i stanowiska paleolityczne Naddniestrza halickiego (The examined loess sites in the Halič Pridnistrov'ja region). In: Madeyska T, ed, Lessy i paleolit Naddniestrza halickiego (Ukraina) (Loess and Palaeolithic of the Dniester River Basin, Halyč region (Ukraine)), Studia Geologica Polonica 119: 33-181.

Łanczont M, Bogucki AB, Fedorowicz S and Kusiak J, 2011. Mesopleistocene loess deposits in the Mamalyha 2 profile of Ukraine interlaboratory comparison of the thermoluminescence dating results. Geochronometria 38(4): 350-358, DOI 10.2478/s13386-0110027-4.

Łanczont M, Bogucki (Bogutskyj) A, Racinowski R, Seul C and Wojtanowicz J, 2003. Eopleistocene and lower Mesopleistocene paleosols in the Zahvizdja profile in the East Carpathian Foreland (W Ukraine). Quaternary International 106-107: 119-130, DOI 10.1016/S1040-6182(02)00167-2.

Łanczont M and Madeyska T, 2009. Skała Podolska - kluczowy profil dolnego czwartorzędu zachodniej Ukrainy (Skala Podil'ska - a key-profile of Older Quaternary in the West Ukraine). Prace Komisji Paleogeografii Czwartorzędu PAU 7: 33-46.

Nawrocki J, Bogucki A, Łanczont M and Nowaczyk NR, 2002. The Matuyama-Brunhes boundary and the nature of magnetic remanence acquisition in the loess-paleosol sequence from western part of the East European loess province. Palaeogeography, Paleoclimatology, Palaeoecology 188(1-2): 39-50, DOI 10.1016/S00310182(02)00528-X.

Rehman A, 1893. Podole Pokuckie (The Pokuttya part of the Podillya Upland). Wszechświat 33(12): 513-516 (in Polish).

Singhvi AK, Sharma YP and Agrawal DP, 1982. Thermoluminescence dating of sand dunes in Rajastan, India. Nature 295(5847): 313315, DOI 10.1038/295313a0.

Veklich MF, 1982. Paleoetapnosts y stratotypy pochoronnykh formatsy verkhnego kaynozoya (Palaeostages and stratotypes of the Upper Cainozoic fossil formations). Naukova Dumka: 1-208 (in Ukrainian).

Teisseyre H, 1933. Problemy morfologiczne wschodniego Podkarpacia (Morphological problems of the East Carpathian Foreland). Sprawozdania Polskiego Instytutu Geologicznego 7(3), Warszawa: 421-454 (in Polish).

Walanus A and Goslar T, 2009. Datowanie radiowęglowe (Radiocarbon dating). Wydawnictwa AGH, Kraków: 147 pp (in Polish).

Zglinnica A, 1931. Regjony morfologiczne na Pokuciu (Les régions morphologiques du Pokucie). Prace Geograficzne wydawane przez prof. E. Romera 12, Lwów: 81-97 (in Polish). 